\title{
THE IMPACT OF THE NUMBER OF RETAIL OUTLETS ON THE MARKET SHARE OF CONSUMER GOODS' RETAIL BRANDS
}

\author{
UDC: 339.188 .2 \\ Original Scientific Paper \\ Marko VLAHOVIĆ ${ }^{1}$, Mila KAVALIĆ ${ }^{2}$, Slađana BORIĆ ${ }^{1}$, Sanja STANISAVLJEV ${ }^{3}$, \\ Nikola ĆURČIĆ ${ }^{4}$ \\ ${ }^{1}$ Republic of Serbia \\ ${ }^{2}$ Republic of Serbia \\ E-mail: mila.zakin@tfzr.rs \\ ${ }^{3}$ University of Novi Sad, Technical faculty “Mihajlo Pupin” Zrenjanin, 23000 Zrenjanin, Đure Đakovića bb, \\ Republic of Serbia \\ ${ }^{4}$ University Union "Nikola Tesla", Faculty for management - FAM, 21205 Sremski Karlovci, Njegoševa 1a, \\ Republic of Serbia
}

Paper received: 25.02.2016.; Revision submitted: 08.04.2016.; Paper accepted: 15.04.2016.

\begin{abstract}
The paper presents the research results of effects of retail brands of consumer goods on the market share they have in Serbia. In particular, the research includes the impact of the retail format on the growth or decrease in market share. The data were obtained from market retailing research of consumer goods on the Internet and the research carried out by the GFK agency. The study used a statistical method of data processing by the method of descriptive statistics. The survey showed that the Serbian retail market is still underdeveloped, and that the strongest impact on the market share of retail chain stores of consumer goods has the size of the retail network, as well as a strong dominance of traditional trade in comparison to organized one. The retail market in Serbia has a long period of consolidation forthcoming and also taking over such a status that organized trades or TOP 10 retail chains have already had in the most developed countries. The market share of TOP 10 retail chains in Serbia is now at the level slightly bigger than $30 \%$, while those in developed market economies have a market share moving up to $75 \%$.
\end{abstract}

Keywords: Retail brands, Consumer goods, Market share, Serbian retail market.

\section{INTRODUCTION}

Modern trade and modern trends in trade are characterized by revolutionary changes that are made of concentration, enlarging trade, raising the level of trade globalization and technological progress in the development of trade embodied in the information revolution and the intense transformation of trade and trade enterprises. All these revolutionary changes have enabled the increased role of trade, so by efficiency and service quality trade has imposed the consumers and producers. Successful business in modern economy is determined by the ability of an enterprise to meet the demands of the market, to track changes which are more and more frequent and dynamic. Competition has become global, so modern enterprises need to appear in the market with global strategies (Stanisavljev et al., 2012). Nowadays, it is very important for an organization to be competitive and to meet both the market and consumers' requirements (Bogetić, 2015). To ensure the value for a consumer, retailers and suppliers must, first, provide a complete, affordable, well exposed range of products that consumers want. Second, the offered range of products must be maintained in an appropriate amount in order to avoid the shortage of goods. Third, the retailer and the supplier have to transmit adequately the benefits and the value of the product to consumers. And fourth, retailers and suppliers have to continually develop and present new products in order to improve the value for the consumer. The assumption of realization of the given improving value processes for consumers are a synchronized strategic development and 
manufacturing, integrated and automated supply and recruitment, as well as logistics without problems (Bogetić \& Aćimović, 2009). Since there is a modern market economy, and long before that, it was hard to imagine economically developed country without trade, and because of this very fact its contribution to the economic development of the country is of great importance. Retailing is one of the oldest businesses that human civilization has known. It acts as an interface between the producer and consumer, improves the flow of goods and services and raises the efficiency of distribution in an economy. For a strong, stable and consistently growing economy, a well organized and efficient retail sector is a must (Dineshkumar \& Vikkraman, 2012). Because of the importance that trade plays in the economic development of many countries, this paper will examine the Serbian retail market of consumer goods. It should be taken in mind that the retail sector is becoming a kind of "arena" in which a sharp competitive struggle for consumers is held. That struggle is becoming more difficult, given to the increasing number of new products that compete for the relatively limited sales area and in terms of limited number of consumers and their purchasing power. Entities operating the conditions for the conduct of the struggle within some kind of competitive retail arena have a leading role in marketing channels (Lovreta \& Stojković, 2012). The main objective of marketing research of the market is to reduce uncertainty and insecurity in business decisions and the risk to the business by collecting, processing and interpreting data. Marketing research is a key element in the whole area of marketing and trade. Sectors for marketing in various companies usually entrust the job of research to agencies that are specialized in this part of the job.

Market research is the functional link between marketing management and an organization's ultimate customer base. As globalization increases, service firms will need to know how to utilize market research approaches that enable them to stay close to these worldwide and diverse customer segments (Javalgi et al., 2006). Lovelock reports that when researching the marketplace, service marketers should attempt to find answers to the following questions: What are the optimal ways to use marketing research information to support an international segmentation strategy for the firm's service? What do customers in each segment view as the firm's competitive advantages? How should the organization differentiate marketing efforts to attract and retain the most optimal customer segments? What is the long-term financial value of a loyal customer in each segment? What other strategies are necessary in order for the organization to build long-term relationships in terms of satisfaction, loyalty, retention and profitability with target segments? How can service marketing research be better integrated into the organization to support improved relationship marketing strategy execution (Lovelock, 2004).

\section{METHODOLOGY}

Primary data in this study represent a research of agency GFK, and refer to the market share of the largest retail chains in Serbia and value share of retail formats in Serbia. Secondary data used in this paper are data on the number of retail outlets and formats of each retail chain that can be found on the official web sites of these chains and trade data that can be downloaded from the website of the Republic Institute for Statistics, which refer to the structure of private consumption and the rate of retail sales of consumer goods at constant and current prices.

\section{Theory and research questions}

Serbian companies have been uncompetitive in international market for a long period of time. Low productivity and insufficient investment in achieving business quality are the main reasons for poor competitiveness of domestic companies. This insufficient competitive ability has become more visible upon the appearance of the world economic crisis (Đorđević et al., 2013). The world financial crisis that emerged in 2008 and which immediately leaked over in Serbia has caused the growth trend of the market share of small shops. According to numerous studies that have been conducted on this occasion, it was found that the majority of customers, due to the great crisis that has arisen, "are afraid" to go to the big stores, because then they always spend more money than they had planned. That statement is substantiated by the fact that big markets make consumers spend more than they have initially planned. Small tactics that everyone applies, but which really works. Some of them are (Minić, 2014): Trams (carts) that were invented in 1938 in order to make it easier to do large purchases. Since then, they have been improved and often increased. It turned out that people averagely spend more money if they are larger and easier to handle; Daily necessities such as milk, eggs, bread and the similar, are located in 
the far end of a shop so the consumers, looking for them would go through the rest of the store and eventually buy something else; these are just some of the tactics of large stores that lead to unplanned spending and the similar. Consumers are certainly in the center of trade; the integral management process in the store at the macro and micro level of its functioning starts and ends with customers (Lovreta et al. 2009). Today, however, consumers have opted to spend far less money on food and to do their purchases at the nearest store. From that point, the development of Serbian retail market has stopped; the retail market is in a consolidation phase and is moving towards the goal to advance from the traditional into organized retail market of consumer goods. For this to happen it is necessary that TOP 10 or the biggest retail chains in Serbia have a total market share exceeding 50\%, and preferably up to $75 \%$, as it is the case in developed countries. The trade in Serbia, as in other transition countries, is characterized by the entry of foreign trade companies, the creation of new enterprises through franchising system, the construction of large retail formats (hypermarkets, supermarkets, Cash \& Carry systems) and so on (Bennison \& Boutsouki, 1995). So, in the last few years, the transition process has influenced the change in the structure of retail to the fullest extent (Radosavljević \& Borisavljević, 2014).

The most significant factors which are missing in developing competitiveness of Serbian companies are the following: new technologies (12.94\%), employees' motivation (11.41\%), education $(9.93 \%)$ and financial support $(9.21 \%)$. According to the interviewees, the following elements are necessary for developing competitive ability of Serbian companies: standardization of business quality (17.22\%), implementation of modern management methods and techniques (17.08\%), investments in development of national brands $(17.08 \%)$ and buying modern technologies (13.02\%) (Đorđević et al., 2011). The research we conducted by using the results of the market research agency GFK, which we were given by the company Mercator-S, helped us to establish the following research questions:

Q1: Did the TOP 10 retail chains record a growth of the total market share of retail consumer goods in the period 2012-2015?

Q2: Have the individual retail chains had significant changes in their market shares and whether these changes affected the change in market share of the TOP 10 group?

Q3: Are there companies in the field of retail sales of consumer goods in the market that are significantly different from other competito-rs?

\section{Household panel}

Primary research is based on the following presumption - the trade companies in Serbia are interested in the same issues popular in all countries worldwide: who buys, what do they buy, where is it purchased, when, how much, how, at what price, etc. All these questions can be answered by market research agency through a survey which is conducted in almost all developed countries; it is called The Household Panel, shown in Figure 1 (Figure 1). GFK Panel Households have 1,500 households which were selected according to geographic and socio-demographic criteria. In this way, the panel represents 2.5 million Serbian households. The participants in the Panel keep detailed records of daily purchases of consumer goods for the needs of their household, through the specific consumption diary. Thanks to the continuous and constant sample, GFK Panel households provide evidence of market trends, enlighten buying behavior and provide information on the development of retail chains, given that it covers all store formats. Today Household Panel exists in 12 countries of Central and Eastern Europe: Austria, Bulgaria, Czech Republic, Croatia, Kazakhstan, Hungary, Poland, Romania, Russia, Serbia, Slovakia and Ukraine.

The market share gained by this research represents the percentage number that indicates the share or the representation of a retailer or producer on a market.

\section{RESULTS}

Before it is determined if there are any changes in the market it is important to look at some of the key parameters of the retail market of consumer goods and conclude if structural changes have occurred in these parameters.

\section{Turnover in retail trade}

The macroeconomic indicator, which has led to a gap in turnover at current and constant prices, is inflation. In the period from 2005 to 2008 , up to the crisis, the Serbian economy was booming, and 
the higher rate of inflation has led to a faster growth in turnover at current prices, although the real purchasing power of citizens grew more slowly. After the crisis of 2008, the turnover at current prices held its annual growth at about the same level, but the reduced economic activity in the country led to a drop in turnover measured at constant prices. The turnover at constant and current prices in retail trade followed from 2005 to 2014 is shown in Figure 2 (Figure 2). The methodology of measuring turnover at current prices shows the total turnover, taking into account the prices which are current, regardless of the number of sold items. The methodology of turnover measuring at constant prices does not take into account inflation and the current prices, but the turnover is viewed in relation to the compared period. The turnover at current prices can only serve you if you want to see how you position yourself in the market compared to the competition in the year you observe, and the turnover data at constant prices can show you your real situation in relation to some of the previous period.

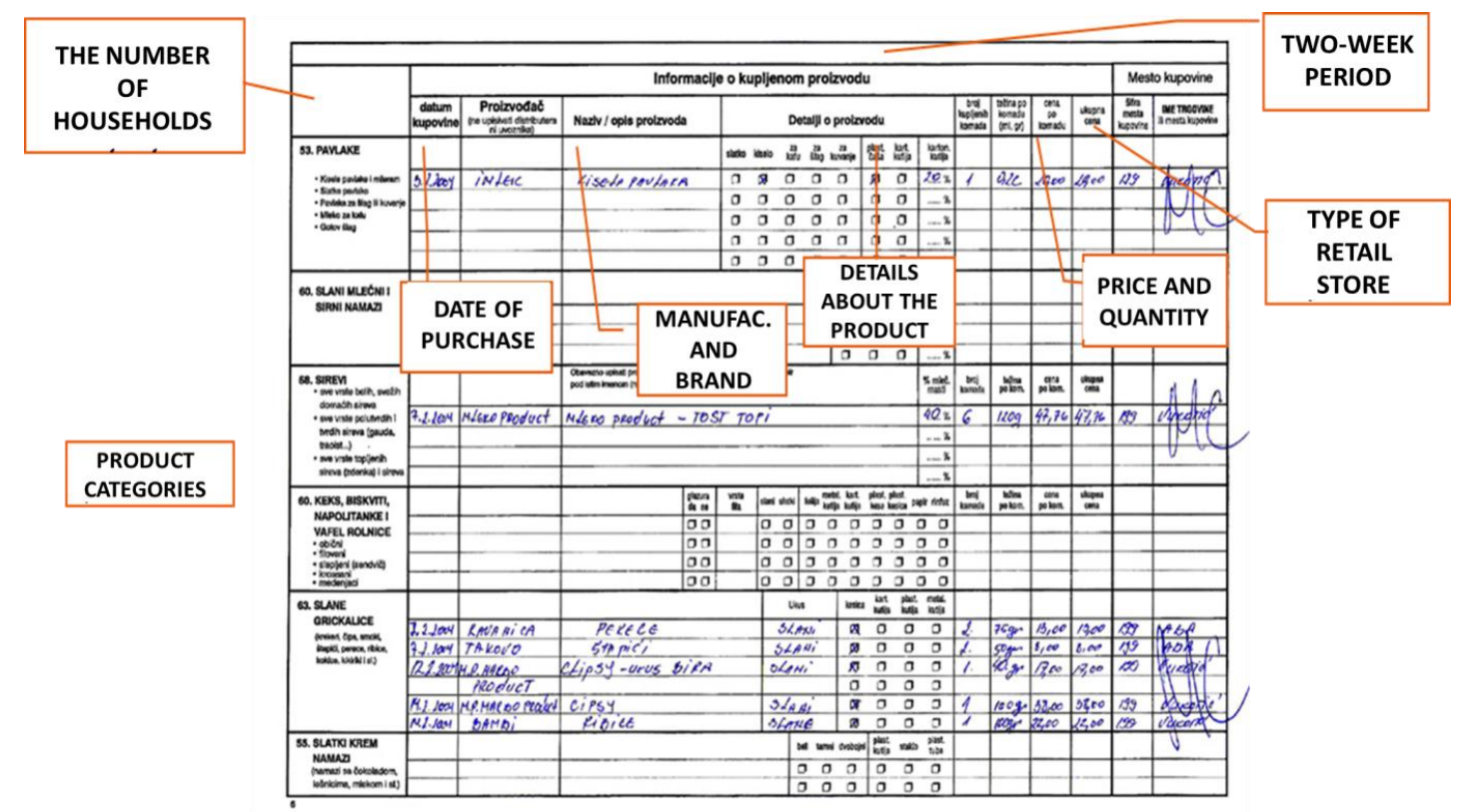

Figure 1: Diary of Panel household Source: GFK Guide for Panel

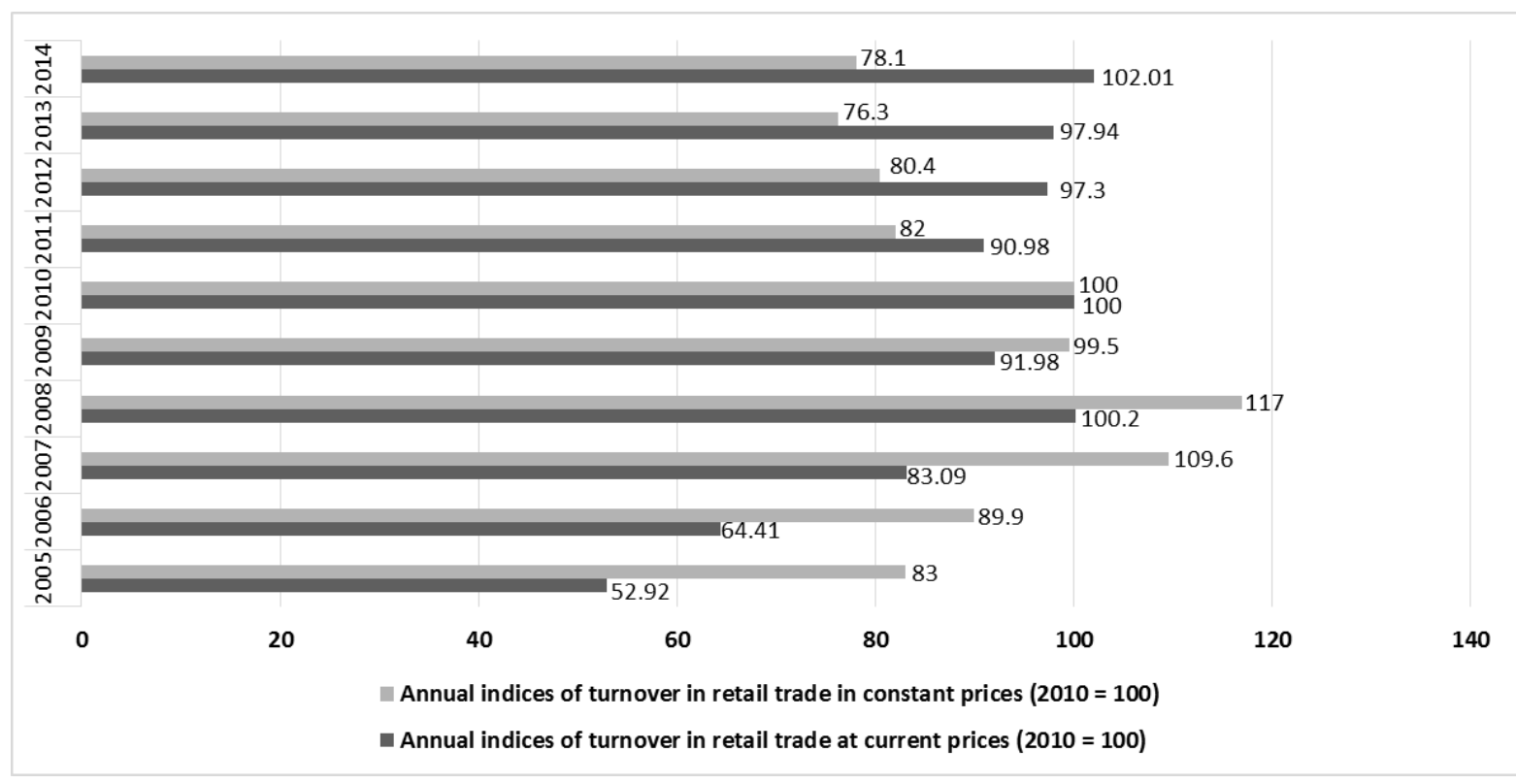

Figure 2: The turnover at constant and current prices in retail trade Source: Statistical Office of the Republic of Serbia 


\section{Personal household consumption}

Personal household consumption helps us look at how customers in a market behave and how they allocate their household budget. From this parameter, it can be concluded to what extent the observed customers are solvent capable. The higher the share of food and beverages in the structure of personal household consumption, the greater the possibility that customers of that market are less solvent capable and that the market is poor. If we look at the table of individual consumption structure of households in Serbia, which is shown in Figure 3 (Figure 3), we can conclude that in the ten-year trend of that factor can be seen the share of all categories that are always displayed on almost the same level. A slight increase in the share of these commodities rises during the formation of the global financial crisis, but already in 2014 it returned to the 2006 level and even goes underneath it. All these changes, as can be seen in Figure 3 (Figure 3), the structures of personal consumption, represent very small changes and, as such, cannot have a significant impact on the average consumer. These small fluctuations in the share of food and beverages are not due to structural changes in the economy or the economy of Serbia, but may represent a trend that has transferred to our market from the world and perhaps from the neighboring countries.

\section{The structure of the retail market in Serbia, according to the format of value participation}

A value structure of the retail market in Serbia shows that in the entire Serbian market the most common formats are supermarkets, small shops and traditional stores, while other formats such as trade market are also significantly represented as shown in Figure 3 (Figure 3). In Figure 4 (Figure 4 ), the decline in the share of organized trade can be seen because in 2014, in comparison to 2012, there was the decline in participation of formats such as hypermarkets, supermarkets and Cash \& Carry, on the other hand, it shows the growth of the traditional and other forms of trade.

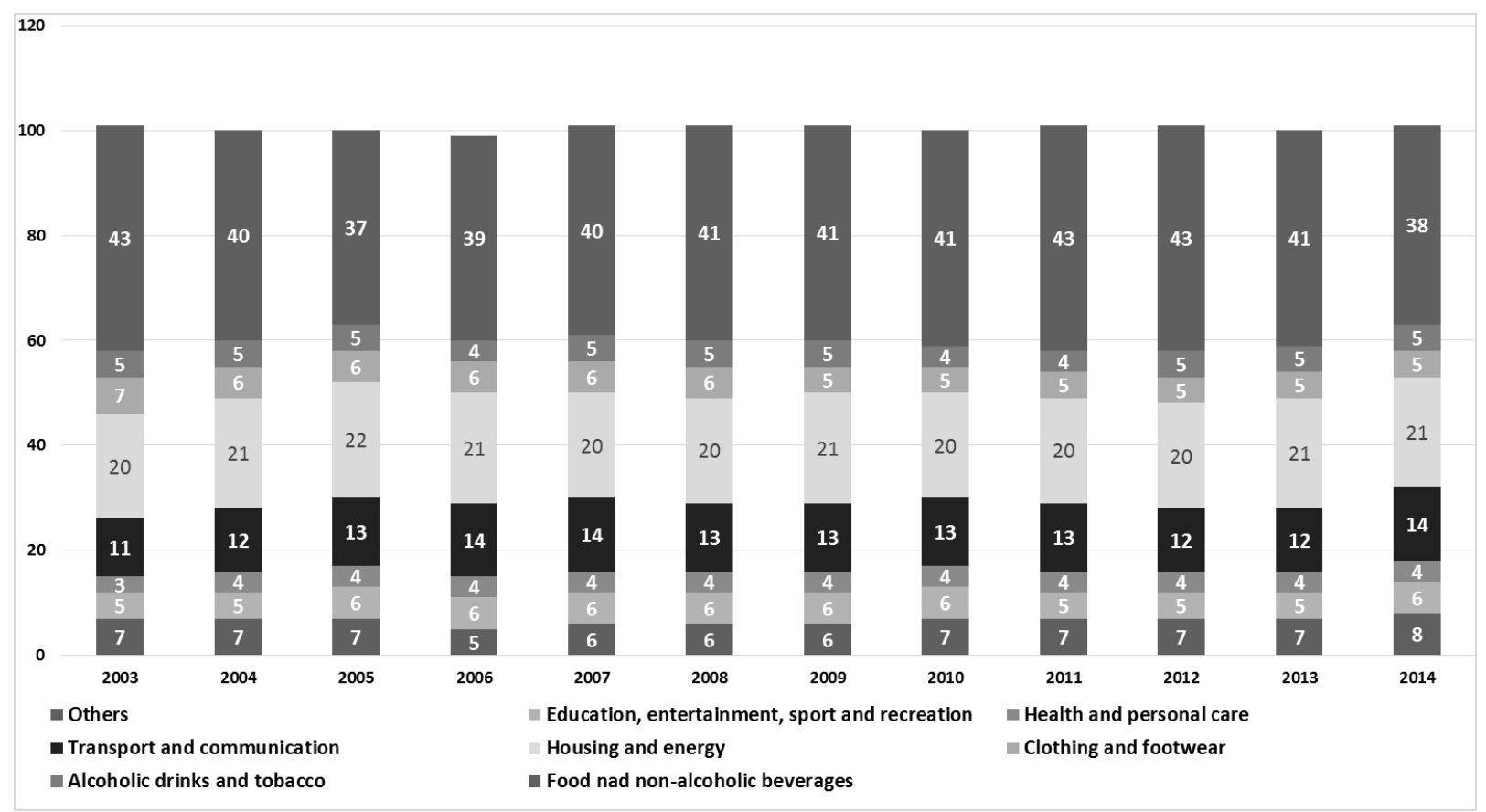

Figure 3: The structure of personal consumption by current prices Source: GFK 2015 / Serbian Retail Monitor 2014/2015

Precisely, these three companies have the largest number of stores in the retail market and the division of its retail network in 2 or 3 brand. In this way customers become "closer" when it comes to assortment and pricing actions. The division of the retail network on 2 or more retail brands allows companies to have a clearer marketing 
communication and so inherently create space for a more precise customers.

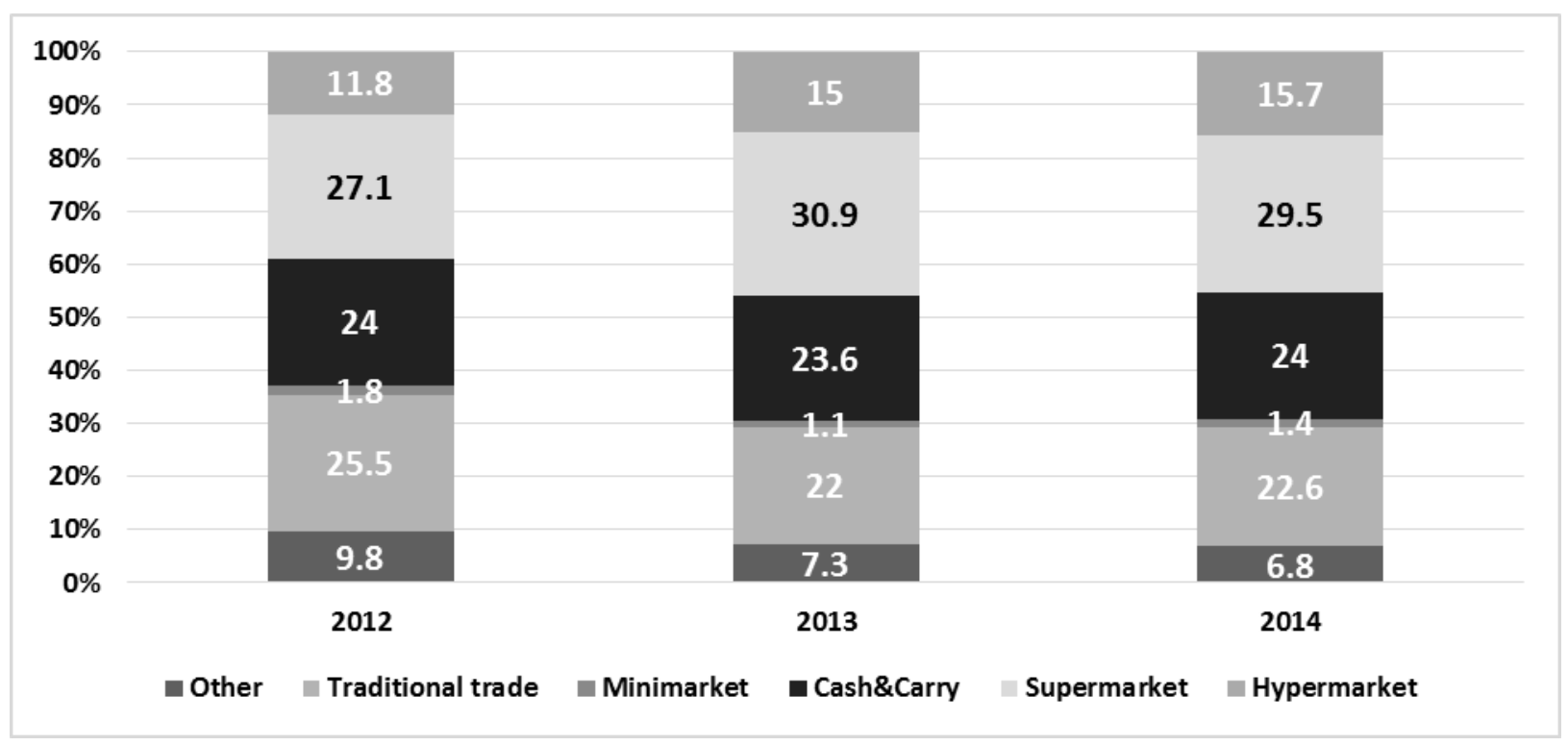

Figure 4: The participation in value of retail formats Source: GFK Serbian Retail Monitor 2014.

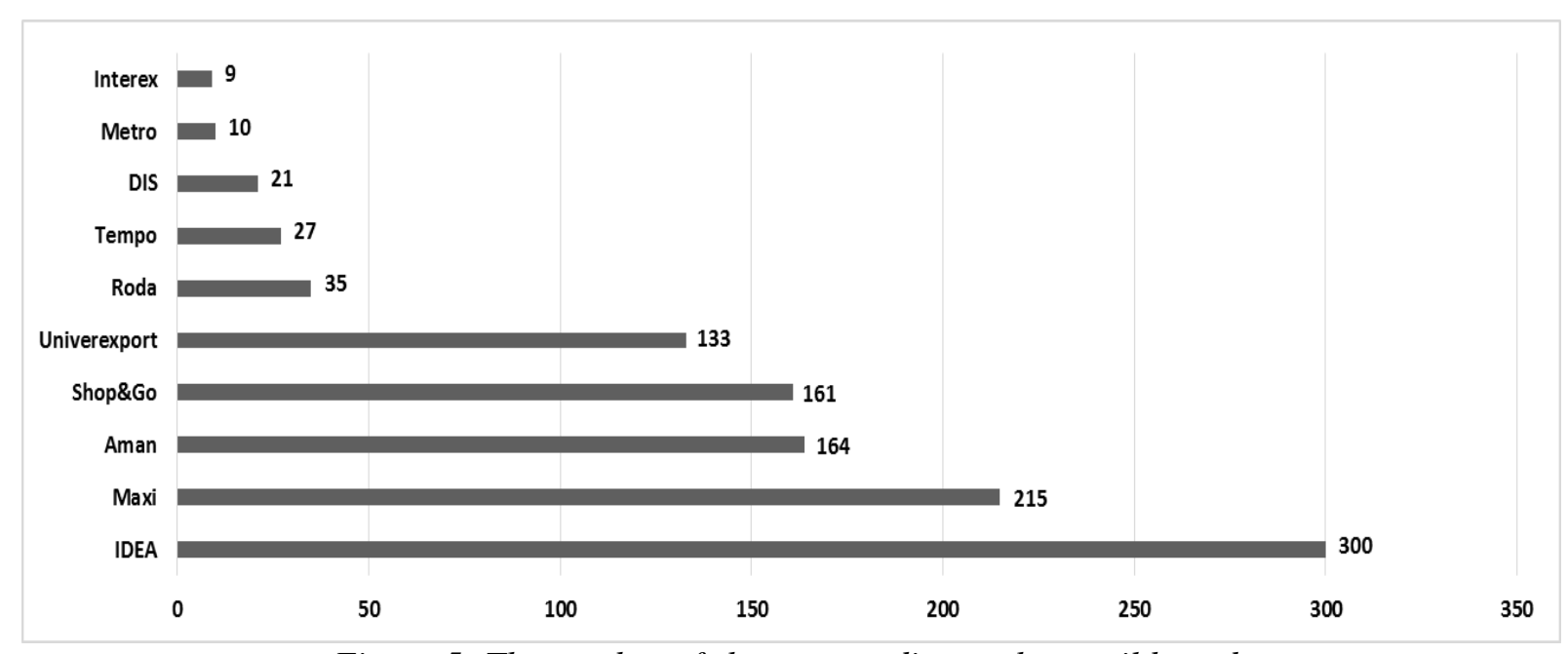

Figure 5: The number of shops according to the retail brands Source: Mercator-S

\section{How customers choose the shop where they will purchase}

The five dimensions we use to review past research are: (1) access, (2) in-store atmosphere, (3) price and promotion, (4) cross-category product/service assortment, and (5) within-category brand/item assortment. The location of a store and the distance that the consumer must pass to get to the shop are basic criteria in their store choice decisions. Beginning with gravity models, (Huff, 1966) store choice and the optimization of retail site location attracted a lot of research attention in the eighties (Achabal et al., 1982; Donthu \& Rust, 1989; Ghosh \& Craig, 1983). The same was confirmed by the survey carried out by the GFK agency. In the study called "Shopping monitor", $40 \%$ of respondents stated closeness as the main factor for the selection of a store. This fact represents the strongest factor influencing the customer's decision on the store choice. In addition, we found out that another dominating factor generally appears to be the factor of good price. These data show that there was a significant increase of those who considered this to be important in 2014/2015 in the selection of shops; but it is very important to note that this factor remained at the same level as in the period 2012/2013 when we talk about the category "major reason". 


\section{Are they loyal to the shops in which they most often purchase?}

Although we could see that the strongest factor in choosing a store in the mentioned table is its closeness, it is useful to know the fact that customers are loyal to stores in which they purchase. Shopping Monitor study conducted by GFK agency shows that more than 50\% of customers say that their purchase is usually done at the same store. Particularly interesting fact is that this data has risen by $6 \%$ points for the period 2014/2013.

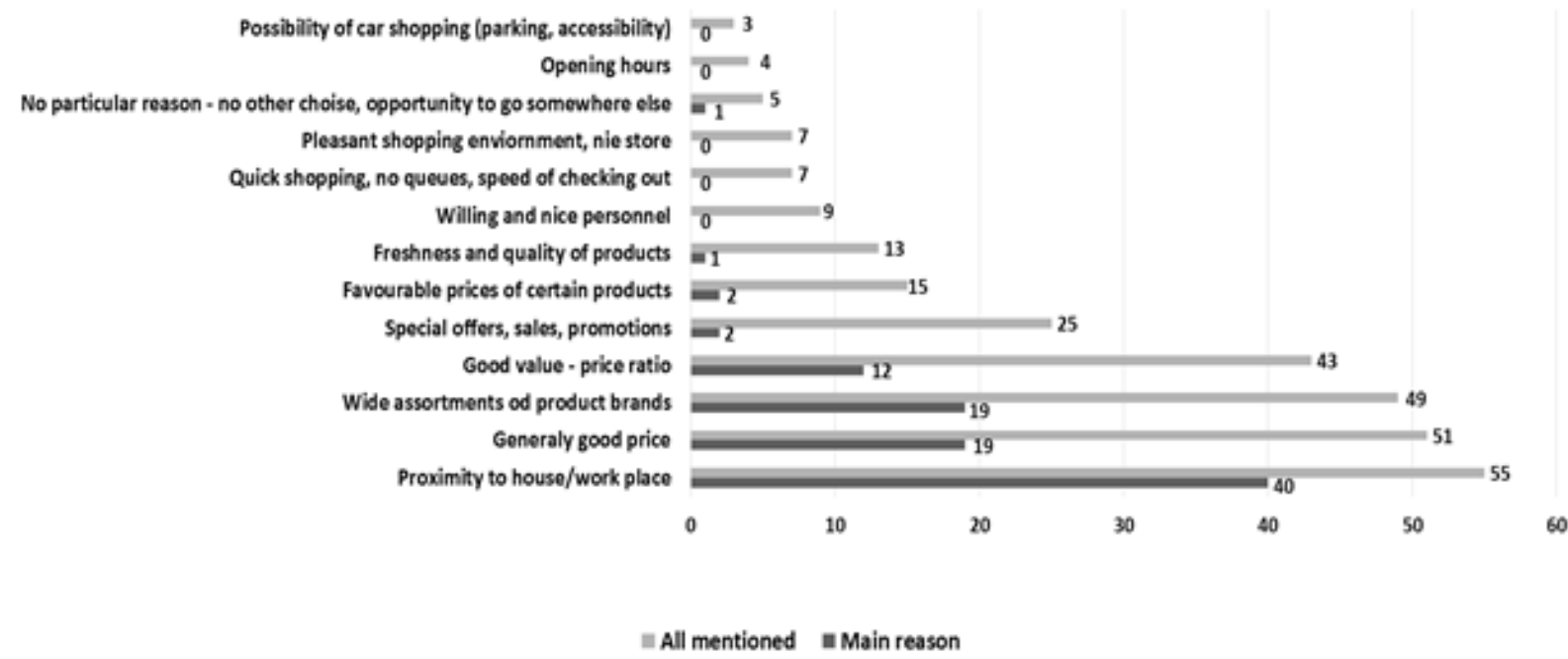

Figure 6: Reasons for choosing main retailers Source: GFK 2015 / Serbian Shopping Monitor 2014/2015

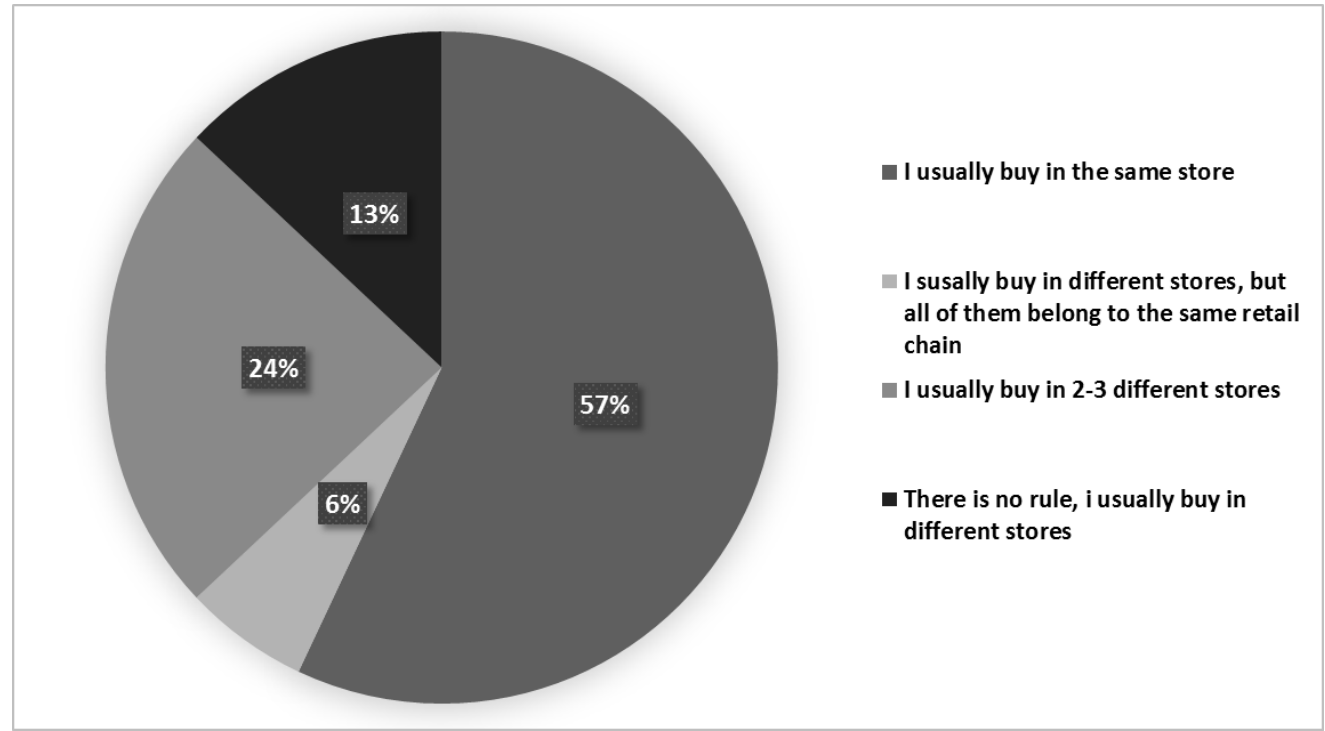

Figure 7: Loyalty when large shopping

Source: GFK 2015 / Serbian Shopping Monitor 2014/2015

\section{Market share measured by the Panel trade method}

In a survey of market share in the period 20122015, which was conducted according to the methodology of panel shops, which we were given by the company Mercator-S, we cannot show it completely because it represents a business secret of the company; but we will state a few facts that will be sufficient to get some useful conclusions from it:

- TOP 10 chain stores at the end of 2012 amounted to $36 \%$ and at the end of 2015 there were only $33.7 \%$,

- The market leader is retailer IDEA, 
- Maxi brand recorded a drop in market share which was created by rebranding Mini Maxi stores in the Shop \& Go brand.

\section{DISCUSSION}

The largest retail chains in Serbia have more than 1,075 stores in all formats in their portfolio, distributed throughout the country. Although all retail chains are very active in marketing and are constantly developing promotional campaigns and other marketing tools to attract customers, in this paper is stated that their market share has not significantly changed, based on the research carried out by the GFK agency. Moreover, there was a decline in 2015 in comparison to 2012, for $2.3 \%$. From researching a market share of retail chains of consumer goods in Serbia, done by GFK agency, whose results we were given by the company Mercator-S, and because of a trade secret we are not able to reveal, it can be seen that the retailer IDEA has recorded the strongest growth in the period 2012-2015. Although we can say that this market share increase is the result of good marketing practice, it is important to note that IDEA increased its network to 100 new stores in the strongest period of growth in the last quarter of 2014. By integrating companies IDEA and Mercator-S, which happened in September 2014, there was a restructuring of the retail network of the brand IDEA and Roda. The company Mercator$S$ has then done redefining retail strategy and decided that the retail brand IDEA becomes a network of small shops and supermarkets, intended primarily for every day purchase, and Roda mega stores to become primarily intended for large weekend purchases. In this redefinition of marketing strategies, 101 Roda stores were taken over by the IDEA retail network, and 11 IDEA large-format stores were taken over by Roda retail network. Then the IDEA, with the earlier 190 of its stores, reached the number of 290 for one month and for just a few months became the market leader. If we take into account that the market share of the company Mercator-S cumulatively did not significantly changed in the period 2014/2015, then we can say that the integration of the two companies has mostly affected the redistribution of market share brands that have got new roles on the Serbian market. In order to completely separate communication for Maxi and Mini Maxi brands in the market, the company Delhaize Serbia decided to rebrand a large number of Mini Maxi stores into a new format, named Shop \& Go. These shops today represent retail network covering the urban areas of cities and municipalities in Serbia and is intended primarily for every day and casual shopping. Although these shops have two completely different marketing approaches to the market from the appearance of new format, it must be noted that there have not been significant changes in the market. Maxi and Shop \& Go together have almost the same market share as well as former Maxi banner before the introduction of the brand Shop \& Go.

Retail chain Univerexport, known for its retail network in Vojvodina, in 2015 managed to return to the level of 2012. This commercial brand in 2013 and 2014 recorded a decline in market share by $26 \%$ compared to the level of the 2012. This decline actually represents the trend TOP 10 retail chains which is recorded in the cumulative negative result. However, in late 2014 and early 2015 the market share growth of Univerexport reached the level of the 2012. The enhanced results can certainly be related to the fact that this retail chain improved its network by acquisition of companies Angropromet and Lurdy supermarkets with about 40 new stores at the end of 2014.

\section{CONCLUSION}

As can be seen from all the above data, retail chains in Serbia have made a significant movement on the markets only because of significant change in their retail networks. Their marketing strategy consisting of a large number of promotional activities and the quality of services at the moment cannot provide the growth of market share that has been expected, precisely because from the data presented it can be seen that in the past few years only with the development of the retail network the market share grew. This is also proved by the fact that research question number 2 is confirmed $(\boldsymbol{Q} 2)$, and it has been shown that the ("Annual indices of turnover in retail trade,")retail chain IDEA had the strongest growth of market share in the reporting period, mainly because its retail network in just one month increased by more than 100 retail stores.

This claim is of course supporting all the other above-mentioned data, which shows that the average Serbian customer usually goes to a nearby shop. The strongest impact on the market share of retail chain stores of consumer goods has the size of the retail network, and therefore there is a strong dominance of traditional trade in comparison to 
organized one. The retail market in Serbia has a long period of consolidation and taking over the status that organized trade or TOP 10 retail chains have in developed countries. The market share of TOP 10 retail chains in Serbia is now at the level that is only slightly greater than $30 \%$, while those in developed market economies have a market share moving up to $75 \%$. The fact that goes in favor of this statement proves the research question number $1(Q 1)$, that indicates that the 10 largest retailers in Serbia recorded a cumulative decline in 2015 compared to 2012.

The Serbian retail market of consumer goods has 2 companies that are very distinguished in comparison to the rest of competitors. Judging by the number of retail stores, Mercator-S and Delhaize Serbia together have about $60 \%$ of all retail establishments of TOP 10 retail chains. However, judging by the survey of panel trade carried out by the GFK agency, whose results we were given by the company Mercator-S, we can say that the company Mercator-S and Delhaize Serbia have about 25\% market share on the Serbian retail market of goods consumption and, as such, are the engine of development of the retail industry in Serbia. This fact confirms the research question number $3(Q 3)$ according to which on the retail market of consumer goods in Serbia there are companies whose market share significantly differs from the rest of the market.

\section{REFERENCES}

Achabal, D., Gorr, W., \& Mahajan, V. (1982). MULTILOC: A multiple store location decision model. Journal of Retailing, 58(summer), 5-25.

Bennison, D., \& Boutsouki, C. (1995). Greek Retailing in Transition. International Journal of Retail \& Distribution Management, 23(1), 24-31.

Bogetić, S. (2015). Interisani menadžment sistemi. Beograd: Beogradska poslovna škola - Visoka škola strukovnih studija.

Bogetić, Z., \& Aćimović, S. (2009). Koncepcija i alati za doba privredne recesije. Montenegrin Journal of Economics. 5(10), 53-63. Montenegrin Journal of Economics. 5(10), 53-63.

Dineshkumar, U., \& Vikkraman, P. (2012). Customers'Satisfaction towards Organized Retail Outlets in Erode City,. IOSR Journal of Business and Management (IOSRJBM), 3(4), 34-40.

Donthu, N., \& Rust, R. (1989). Estimating geographic customer densities using kernel density estimation. Market Science, 8(spring), 191-203.

Đorđević, D., Ćoćkalo, D., \& Đurin, S. (2011). Serbian enterprises and global competition challenges.
Journal of Engineering Management and Competitiveness (JEMC), 1(1/2), 27-31.

Đorđević, D., Sajfert, D., \& Gligorović, B. (2013.). Quality management concept and competitiveness of Serbian companies. Journal Of Engineering Management and Competitiveness (JEMC), 3(2), 7984.

GFK. (2015). Internal date "Diary of Panel household" Shopping monitor 2014/2015

GFK. (2015 ). Internal date "The structure of personal consumption by current prices" Shopping monitor 2014/2015

GFK. (2015). Internal date "The participation in value of retail formats" Retail monitor 2014/2015

GFK. (2015). Internal date "Loyalty when large shopping" Retail monitor 2014/2015

GFK. (2015). Internal date "Reasons for choosing main retailers" Retail monitor 2014/2015

Ghosh, A., \& Craig, S. (1983). Formulating retail location strat-egy in a changing environment. Journal of Marketing, 47(summer), 56-66.

Huff, D. L. (1966). A programmed solution for approximating an optimum retail location. Land Economics, 42(9), 293-303.

Javalgi, R., Martin, C., \& Young, R. (2006). Marketing research, market orientation and CRM. Journal of Services Marketing, 20(1), 12-23.

Lovelock, C. (2004). Services Marketing: People, Technology, Strategy. New York: Prentice-Hall Inc., Upper Saddle River.

Lovreta, S., \& Stojković, D. (2012). Uloga korporativne i javne politike u ostvarivanju održivog razvoja trgovine. TRADE PERSPECTIVES 2012: Trade in the Context of Sustainable Development (pp. 37-59). Beograd: Faculty of Economics, University of Belgrade.

Lovreta, S., Manić, E., \& Stojković, D. (2009). Model for Managing Trade Policy in Cerating Modern Market Economy. International Conference "Economic Policy and Global Recession" (pp. 175184). Belegrade: Faculty of Economics, University of Belgrade.

Mercator-S. (2016). Internal data "The number of shops according to the retail brands".

Minić, I. (2014). Kako funkcioniše supermarket iznutra? , from http://ftw.rs/kako-funkcionisesupermarket-iznura/

Radosavljević, G., \& Borisavljević, K. (2014). Stanje i perspektive ekonomskog razvoja grada Kragujevca Opšti pokazatelji stanja i razvoja trgovinske mreže u Šumadiji (pp. 205-219).

Stanisavljev, S., Đrođević, D., \& Ćoćkalo, D. (2012). Analysis of competitiveness of domestic enterprises on the global market., Singidunum Journal, 9(1), 18.

Statistical Office of the Republic of Serbia. (2016). Annual indices of turnover in retail trade. Belgrade: Statistical Office of the Republic of Serbia 


\section{UTICAJ BROJA MALOPRODAJNIH OBJEKATA NA TRŽIŠNO UČEŠĆE MALOPRODAJNIH BRENDOVA ROBE ŠIROKE POTROŠNJE}

U radu su prikazani rezultati istraživanja uticaja brendova maloprodajnih brendova robe široke potrošnje na tržišno učešče koje imaju u Srbiji. Konkretno, istraživanje obuhvata uticaj maloprodajnog formata na rast ili pad tržišnog učešća. Podaci su dobijeni istraživanjem tržišta maloprodaje robe široke potrošnje na internetu i rezultatima istraživanja koje je uradila agencije GFK. U istraživanju je korišćena metoda statističke obrade podataka putem metode deskriptivne statistike. Istraživanjem se pokazalo da srpsko tržište maloprodaje je još uvek nedovoljno razvijeno, a da najsnažniji uticaj na tržišno učešće trgovinskih lanaca maloprodaje robe široke potrošnje ima veličina maloprodajne mreže, kao i da je prisutna snažna dominacija tradicionalne trgovine u odnosu na organizovanu. Tržištu maloprodaje u Srbiji predstoji dug period konsolidacije i zauzimanje statusa kakav organizovana trgovina, odnosno TOP 10 trgovinskih lanaca ima u najrazvijenijim zemljma sveta. Tržišno učešće TOP 10 trgovinskih lanaca u Srbiji je danas na niovu koji je tek nešto veći od $30 \%$, dok oni u razvijenim tržišnim privredama imaju tržišni udeo koji se kreće čak i do $75 \%$.

Ključne reči: maloprodajni brendovi, roba široke potrošnje, tržišno učešće, srpsko tržište maloprodaje. 